\title{
The NTI-tss device for the therapy of bruxism, temporomandibular disorders, and headache - Where do we stand? A qualitative systematic review of the literature Henrike Stapelmann ${ }^{1}$ and Jens C Türp*1,2
}

\author{
Address: ${ }^{1}$ Clinic for Reconstructive Dentistry and Temporomandibular Disorders, Dental School, Hebelstrasse 3, 4056 Basel, Switzerland and \\ 2Interuniversity College for Health and Development Graz/Castle of Seggau, Austria \\ Email: Henrike Stapelmann - h.stapelmann@unibas.ch; Jens C Türp* - jens.tuerp@unibas.ch \\ * Corresponding author
}

Published: 29 July 2008

BMC Oral Health 2008, 8:22 doi:I0.1 | 86/|472-683|-8-22
Received: 7 February 2008

Accepted: 29 July 2008

This article is available from: http://www.biomedcentral.com//472-683I/8/22

(C) 2008 Stapelmann and Türp; licensee BioMed Central Ltd.

This is an Open Access article distributed under the terms of the Creative Commons Attribution License (http://creativecommons.org/licenses/by/2.0), which permits unrestricted use, distribution, and reproduction in any medium, provided the original work is properly cited.

\begin{abstract}
Background: The NTI-tss device is an anterior bite stop, which, according to the manufacturer, is indicated for the prevention and treatment of bruxism, temporomandibular disorders (TMDs), tension-type headaches, and migraine. The aim of this systematic review was to appraise the currently available evidence regarding the efficacy and safety of the NTI-tss splint.
\end{abstract}

Methods: We performed a systematic search in nine electronic databases and in NTI-tssassociated websites (last update: December $3 \mathrm{I}, 2007$ ). The reference lists of all relevant articles were perused. Five levels of scientific quality were distinguished. Reporting quality of articles about randomized controlled trials (RCTs) was evaluated using the Jadad score. To identify adverse events, we searched in the identified publications and in the MAUDE database.

Results: Nine of 68 relevant publications reported about the results of five different RCTs. Two RCTs concentrated on electromyographic (EMG) investigations in patients with TMDs and concomitant bruxism (Baad-Hansen et al 2007, Jadad score: 4) or with bruxism alone (Kavaklı 2006, Jadad score: 2); in both studies, compared to an occlusal stabilization splint the NTI-tss device showed significant reduction of EMG activity. Two RCTs focused exclusively on TMD patients; in one trial (Magnusson et al 2004, Jadad score: 3), a stabilization appliance led to greater improvement than an NTI-tss device, while in the other study (Jokstad et al 2005, Jadad score: 5) no difference was found. In one RCT (Shankland 2002, Jadad score: I), patients with tension-type headache or migraine responded more favorably to the NTI-tss splint than to a bleaching tray. NTItss-induced complications related predominantly to single teeth or to the occlusion.

Conclusion: Evidence from RCTs suggests that the NTI-tss device may be successfully used for the management of bruxism and TMDs. However, to avoid potential unwanted effects, it should be chosen only if certain a patient will be compliant with follow-up appointments. The NTI-tss bite splint may be justified when a reduction of jaw closer muscle activity (e.g., jaw clenching or tooth grinding) is desired, or as an emergency device in patients with acute temporomandibular pain and, possibly, restricted jaw opening. 


\section{Background}

In July 1998, the U.S. Food and Drug Administration (FDA) granted approval for the "NTI Clenching Suppression System" (now: "Nociceptive Trigeminal Inhibition Tension Suppression System": NTI-tss). According to the manufacturer, the NTI-tss device is indicated for the prevention and treatment of bruxism, temporomandibular disorders (TMDs), occlusal trauma, tension-type headaches and/or migraine [1].

The NTI-tss device is a small pre-fabricated anterior bite stop (Figure 1) which covers - in its most widely used form - the two maxillary (or mandibular) central incisors (Figure 2). The fit along the teeth is accomplished at the chair side by filling either an autopolymerizing acrylate or a thermoplastic material into the base of the device, which is subsequently adapted along the central incisors, thereby increasing the vertical dimension between the upper and lower jaw. Adjustments along the outer surface of the bite stop are made by the dentist to ensure that at jaw closure and during excursive movements tooth contacts are present only between the intraoral device and the incisal embrasures of the antagonistic teeth. This "miniature anterior bite appliance" [2] is typically worn during the night, although two variations of the bite stop are offered for daytime use [3].

In the lay press, most articles have reported positively about the NTI-tss splint in the therapy of long-lasting headache or facial pain [e.g., [4-6]]. Likewise, excited dental practitioners have published their personal impressions in local dental journals [e.g., [7]] or on the website of the international NTI-tss provider e-motion [3].

Conversely, some renowned clinical researchers [e.g., [812]] have tempered over-optimistic expectations by raising doubts on the claimed success and by pointing at the

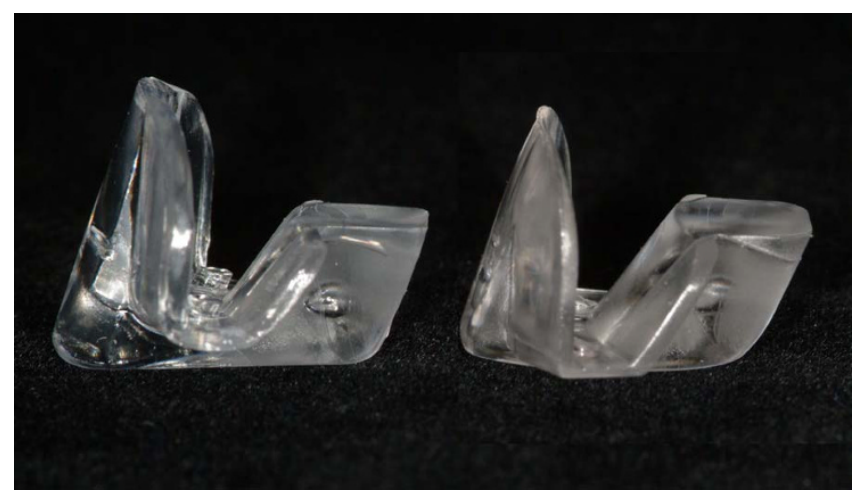

\section{Figure I}

The NTI-tss device, standard type (left) and vertically reduced type (right).

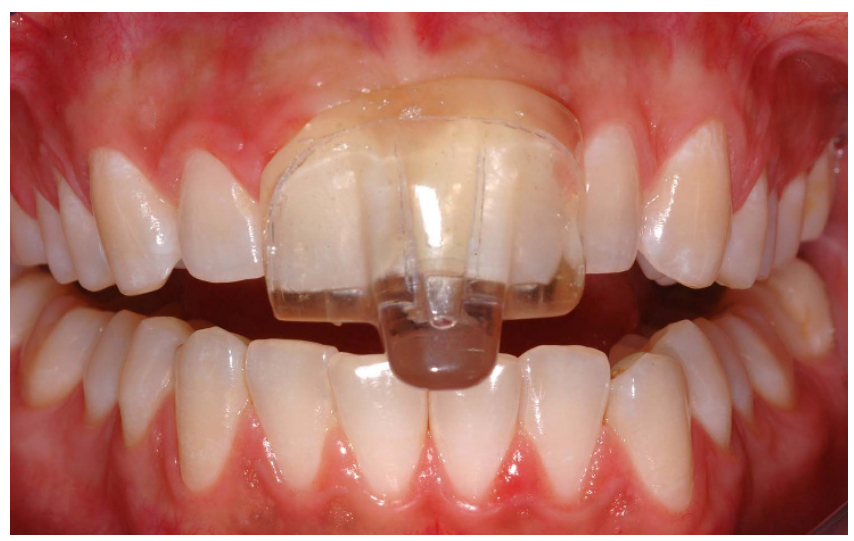

Figure 2

Inserted NTI-tss device.

possibility of unwanted side effects, such as aspiration, ingestion, occlusal changes after prolonged unmonitored use, and mobility of anterior teeth. In 2003, Helkimo [8] delivered an expert statement on demand of the Swedish Dental Association and the Swedish National Board of Health and Welfare on the question whether the use of the NTI-tss device "is to be regarded as lege artis and according to science and empirical experience, both as to the treatment of stomatognathic problems as well as migraine." The author came to the conclusion that there is a "total lack of scientific documentation of its therapeutic effects and possible unwanted side-effects" [8]. As far as side effects are concerned, Jokstad et al [10] mentioned that one person in Norway [13] and three individuals in the United States were subjected to medical emergencies due to aspirated NTI-tss devices splints. For the three cases from the U.S., the author referred to the FDA's Manufacturer and User Facility Device Experience Database (MAUDE), which contains voluntary, user facility, distributor, and manufacturer reports of adverse events involving medical devices. Later, Wright and Jundt [12] repeated the contention of four aspirated NTI-tss devices by referring Jokstad et al's article [10].

Considering the controversy that exists within parts of the international dental community regarding the benefits and dangers of the NTI-tss device, it appears to be timely to

(a) systematically review the (dental) literature in order to summarize and appraise the currently available data on the efficacy and/or effectiveness of the NTI-tss device, and

(b) to summarize all identifiable documented cases, in which complications and/or side effects associated with 
this anterior bite stop have been reported in the dental literature.

\section{Methods \\ Identification of publications about the efficacy and/or effectiveness of the NTI-tss device}

To identify a maximum number of relevant publications (including dental congress abstracts), we performed a systematic search in the following electronic databases:

1. The Cochrane Library

2. PubMed

3. TRIP database

\section{MEDPILOT.DE}

\section{BIREME}

6. The database of the Deutscher Ärzte-Verlag, which comprises the four German-language dental journals "Deutsche Zahnärztliche Zeitschrift", "Zeitschrift für Zahnärztliche Implantologie", "Oralprophylaxe \& Kinderzahnheilkunde", and "Zahnärztliche Mitteilungen"

7. The database of the Quintessenz Verlag, which considers the seven German-language dental journals "Die Quintessenz", „Kieferorthopädie", "Parodontologie“, „Implantologie“, ,Endodontologie“, "Quintessenz TeamJournal" and "Quintessenz Zahntechnik"

\section{Google Scholar}

\section{Web of Science (Cited reference search)}

The key words and strategies for the searches in each of the nine databases are shown in Tables 1 to 9. Moreover, were searched NTI-tss-associated websites for relevant articles and references.
The last update of all electronic searches was carried out on December 31, 2007.

In addition to the database search, textbooks related to the topics of TMDs, occlusion, and bruxism were considered. Furthermore, the Swiss provider (Karr Dental) and an international European provider of the NTI-tss device (emotion) were requested to send us possible further material and publications. The abstracts, or, when available, the full-text papers were read in order to establish the acceptability of the publications to this review. Finally, the reference lists of the identified relevant articles were screened to find additional pertinent contributions (e.g., journal articles, textbooks, book chapters, master or doctoral theses, course material).

The strength of evidence related to the identified publications was evaluated using the classification suggested by Antes [14] (Table 10). Articles about randomized controlled trials (RCTs) were evaluated according to the quality score developed by Jadad et al [15]. The Jadad scale consists of five items, which focus on three dimensions of internal validity (randomization; double blinding; description of withdrawals and drop-outs) (Table 11). Since double-blinding (as required in the Jadad scale) is not possible when occlusal devices are used, single-blinding of the investigator(s) to the type of splint worn by the patient was used as criterion.

Uncertainties on data interpretation and discrepancies in scoring according to the classifications by Antes [14] as well as Jadad et al [15] were resolved by discussion between the two reviewers.

\section{Identification of publications about complications and/or side effects of the NTI-tss device}

For the identification of complications and/or side effects associated with the use of the NTI-tss device, pertinent reports found in the identified articles using the search strategies mentioned above were considered.

Table I: The Cochrane Library.

\begin{tabular}{|c|c|c|c|c|c|}
\hline$\#$ & Search terms & Hits & Relevant hits & Cumulative relevant hits & Reference \\
\hline I & NTI & 10 & 2 & 2 & {$[9,10]$} \\
\hline 2 & NTI-tss & 0 & & & \\
\hline \multirow[t]{4}{*}{3} & NTI* & Cochrane reviews: II & 0 & & \\
\hline & & clinical trials: 37 & 2 & 2 & \\
\hline & & methodological studies: 2 & 0 & & \\
\hline & & economic evaluation: I & 0 & & \\
\hline 4 & nociceptive trigeminal inhibition & 5 & 4 & 5 & {$[16-18]$} \\
\hline 5 & nociceptiv* trigeminal inhibition & 6 & 5 & 5 & \\
\hline 6 & anterior deprogrammer & 0 & & & \\
\hline
\end{tabular}


Table 2: PubMed.

\begin{tabular}{|c|c|c|c|c|c|}
\hline \# & Search terms & Hits & Relevant hits & Cumulative relevant hits & (New) Relevant references \\
\hline 1 & NTI & 195 & 7 & 7 & {$[9,10,12,22,60-62]$} \\
\hline 2 & NTI-tss & 0 & & & \\
\hline 3 & NTI* & 355 & 7 & 7 & \\
\hline 4 & nociceptive trigeminal inhibition & 107 & 4 & 10 & {$[16-18]$} \\
\hline 5 & nociceptiv* trigeminal inhibition & 108 & 5 & 10 & \\
\hline 6 & anterior deprogrammer & 2 & 0 & & \\
\hline 7 & "Temporomandibular Joint Disorders"[MeSH] AND NTI & 7 & 7 & 10 & \\
\hline 8 & "Temporomandibular Joint Disorders"[MeSH] AND NTI-tss & 0 & & & \\
\hline 9 & "Temporomandibular Joint Dysfunction Syndrome"[MeSH] AND NTI & 0 & & & \\
\hline \multirow[t]{2}{*}{10} & "Temporomandibular Joint Dysfunction Syndrome"[MeSH] AND NTI-tss & 0 & & & \\
\hline & Clinical queries; therapy, broad sensitive search: & & & & \\
\hline 11 & $\begin{array}{l}\text { (NTI) AND ((clinical [Title/Abstract] AND trial [Title/Abstract]) OR clinical trials } \\
{[\text { MeSH Terms] OR clinical trial [Publication Type] OR random* [Title/Abstract] OR }} \\
\text { random allocation [MeSH Terms] OR therapeutic use [MeSH Subheading]) }\end{array}$ & 42 & 4 & 10 & \\
\hline 12 & $\begin{array}{l}\text { (NTI-tss) AND ((clinical [Title/Abstract] AND trial [Title/Abstract]) OR clinical trials } \\
{[\text { MeSH Terms] OR clinical trial [Publication Type] OR random* [Title/Abstract] OR }} \\
\text { random allocation [MeSH Terms] OR therapeutic use [MeSH Subheading]) }\end{array}$ & 0 & & & \\
\hline 13 & $\begin{array}{l}\text { (NTI*) AND ((clinical [Title/Abstract] AND trial [Title/Abstract]) OR clinical trials } \\
{[\text { MeSH Terms] OR clinical trial [Publication Type] OR random* [Title/Abstract] OR }} \\
\text { random allocation [MeSH Terms] OR therapeutic use [MeSH Subheading]) }\end{array}$ & 98 & 4 & 10 & \\
\hline 14 & $\begin{array}{l}\text { (Nociceptive trigeminal inhibition) AND ((clinical [Title/Abstract] AND trial [Title/ } \\
\text { Abstract]) OR clinical trials [MeSH Terms] OR clinical trial [Publication Type] OR } \\
\text { random* [Title/Abstract] OR random allocation [MeSH Terms] OR therapeutic use } \\
{[\text { MeSH Subheading]) }}\end{array}$ & 25 & 4 & 10 & \\
\hline 15 & $\begin{array}{l}\text { (Nociceptiv* trigeminal inhibition) AND ((clinical [Title/Abstract] AND trial [Title/ } \\
\text { Abstract]) OR clinical trials [MeSH Terms] OR clinical trial [Publication Type] OR } \\
\text { random* [Title/Abstract] OR random allocation [MeSH Terms] OR therapeutic use } \\
\text { [MeSH Subheading]) }\end{array}$ & 26 & 5 & 10 & \\
\hline 16 & $\begin{array}{l}\text { (Anterior deprogrammer) AND ((clinical [Title/Abstract] AND trial [Title/Abstract]) } \\
\text { OR clinical trials [MeSH Terms] OR clinical trial [Publication Type] OR random* } \\
\text { [Title/Abstract] OR random allocation [MeSH Terms] OR therapeutic use [MeSH } \\
\text { Subheading]) }\end{array}$ & 0 & & & \\
\hline
\end{tabular}


Table 3: TRIP database.

\begin{tabular}{|c|c|c|c|c|c|}
\hline \# & Search terms & Hits & $\begin{array}{l}\text { Relevant } \\
\text { hits }\end{array}$ & $\begin{array}{c}\text { Cumulative relevant } \\
\text { hits }\end{array}$ & $\begin{array}{l}\text { (New) Relevant } \\
\text { references }\end{array}$ \\
\hline \multirow[t]{11}{*}{$\mathrm{I}$} & NTI & evidence-based Synopses: I & 0 & & \\
\hline & & guidelines: 2 & 0 & & \\
\hline & & clinical questions: I & 0 & & \\
\hline & & E-textbooks: I & 0 & & \\
\hline & & other: I & 0 & & \\
\hline & & Medline: & & & \\
\hline & & therapy: 9 & 3 & 3 & {$[9,10,22]$} \\
\hline & & diagnosis: 8 & 0 & & \\
\hline & & systematic reviews: 4 & 0 & & \\
\hline & & prognosis: 8 & 0 & & \\
\hline & & etiology: 5 & 0 & & \\
\hline 2 & NTI-tss & 0 & 0 & 3 & \\
\hline \multirow[t]{12}{*}{3} & NTI* & systematic reviews: 207 & 0 & & \\
\hline & & evidence-based synopses: 17 & 0 & & \\
\hline & & guidelines: 33 & 0 & & \\
\hline & & clinical questions: 33 & 0 & & \\
\hline & & E-textbooks: 19 & 0 & & \\
\hline & & More: 3 & 0 & & \\
\hline & & Medline: & & & \\
\hline & & therapy: 16 & 3 & 3 & \\
\hline & & diagnosis: II & 0 & & \\
\hline & & systematic reviews: 26 & 0 & & \\
\hline & & prognosis: 16 & 0 & & \\
\hline & & etiology: 15 & & & \\
\hline \multirow[t]{9}{*}{4} & nociceptive trigeminal & systematic reviews: I & 0 & & \\
\hline & & Guidelines: 3 & 0 & & \\
\hline & & E-textbooks: 9 & 0 & & \\
\hline & & Medline: & & & \\
\hline & & therapy: 6 & 4 & 6 & {$[16-18]$} \\
\hline & & diagnosis: 2 & 0 & & \\
\hline & & systematic reviews: 0 & & & \\
\hline & & prognosis: I & 0 & & \\
\hline & & etiology: 0 & & & \\
\hline \multirow[t]{9}{*}{5} & nociceptiv* trigeminal & systematic reviews: I & 0 & & \\
\hline & & guidelines: 3 & 0 & & \\
\hline & & E-textbooks:9 & 0 & & \\
\hline & & Medline: & & & \\
\hline & & therapy: 8 & 5 & 6 & \\
\hline & & diagnosis: 2 & 0 & & \\
\hline & & systematic reviews: 0 & 0 & & \\
\hline & & prognosis: I & 0 & & \\
\hline & & etiology: 0 & & & \\
\hline 6 & anterior deprogrammer & 0 & & & \\
\hline
\end{tabular}

Search strategy and results (search date: December 3I, 2007) 
Table 4: MedPilot.

\begin{tabular}{|c|c|c|c|c|c|}
\hline \# & Search terms & Hits & Relevant hits & Cumulative relevant hits & (New) Relevant references \\
\hline \multirow[t]{3}{*}{1} & NTI & All: 396 & & & \\
\hline & & Medline: 357 & 7 & 7 & {$[9,10,12,22,60-62]$} \\
\hline & & in others 5 & 0 & & \\
\hline 2 & NTI-tss & 0 & & & \\
\hline 3 & NTI* & 825 Medline: 538 & (see PubMed search) & & \\
\hline 4 & nociceptive trigeminal inhibition & I57 Medline: 156 & 4 & 10 & {$[17,16,18]$} \\
\hline 5 & nociceptiv* trigeminal inhibition & I57 Medline: I 56 & 4 & 10 & \\
\hline 6 & anterior deprogrammer & Medline: 4 & 0 & 10 & \\
\hline
\end{tabular}

Search strategy and results (search date: December 31, 2007)

Table 5: BIREME.

\begin{tabular}{|c|c|c|c|c|c|}
\hline \# & Search terms & Hits & Relevant hits & $\begin{array}{l}\text { Cumulative } \\
\text { relevant hits }\end{array}$ & (New) Relevant references \\
\hline \multirow[t]{9}{*}{1} & NTI & General Health Sciences (190): & & & \\
\hline & & LILACS: 5 & 0 & & \\
\hline & & Medline: 161 & (see PubMed search) & & \\
\hline & & Cochrane Library: 23 & 0 & & \\
\hline & & SciELO: I & 0 & & \\
\hline & & Specialized Areas (1): & & & \\
\hline & & BBO: I & 0 & & \\
\hline & & International Agencies (1): & & & \\
\hline & & WHOLIS: I & 0 & & \\
\hline 2 & NTI-tss & 0 & & & \\
\hline 3 & NTI* & 0 & & & \\
\hline \multirow[t]{3}{*}{4} & nociceptive trigeminal & General Health Sciences (I |4): & & & \\
\hline & & Medline: 102 & (see PubMed search) & & \\
\hline & & Cochrane Library: 12 & 0 & & \\
\hline 5 & $\begin{array}{l}\text { nociceptiv* trigeminal } \\
\text { inhibition }\end{array}$ & 0 & & & \\
\hline \multirow[t]{3}{*}{6} & anterior deprogrammer & General Health Sciences (3): & & & \\
\hline & & LILACS: I & 0 & & \\
\hline & & Medline: 2 & 0 & & \\
\hline
\end{tabular}

Search strategy and results (search date: December 31, 2007)

Table 6: Database of the Deutsche Ärzte Verlag.

\begin{tabular}{lll}
\hline$\#$ & Search terms & Hits \\
\hline I & NTI & 0 \\
2 & NTI-tss & 0 \\
3 & NTI* & 0 \\
4 & nociceptive trigeminale Inhibition & 0 \\
5 & nociceptiv* trigeminale Inhibition & 0 \\
6 & anteriorer Deprogrammierer & 0 \\
\hline
\end{tabular}

Search strategy and results (search date: December 31, 2007)
Table 7: Database of the Deutsche Quintessenz Verlag.

\begin{tabular}{llc}
\hline$\#$ & Search terms & Hits \\
\hline I & NTI & 3062 \\
2 & NTI-tss & 0 \\
3 & NTI* & 0 \\
4 & nociceptive trigeminal inhibition & 0 \\
5 & nociceptiv* trigeminal inhibition & 0 \\
6 & anterior deprogrammer & 0
\end{tabular}

Search strategy and results (search date: December 3I, 2007) 
Table 8: Google Scholar.

\begin{tabular}{llcccc}
\hline \# & Search terms & Hits & Relevant hits & Cumulative relevant hits & (New) Relevant references \\
\hline I & NTI & about 95,000 & & & 18 \\
2 & NTI-tss & 28 & 18 & & {$[1,3,8,10,16,24,26,36,63-72]$} \\
3 & NTI* & 93,400 & & 20 & {$[10,19]$} \\
4 & nociceptive trigeminal inhibition & 8,760 & 2 & 20 & {$[18$} \\
5 & nociceptiv* trigeminal inhibition & 18 & 2 & \\
6 & anterior deprogrammer & 37 & 20 & \\
\hline
\end{tabular}

Search strategy and results (search date: December 3I, 2007)

Table 9: Web of Science: Cited reference search.

\begin{tabular}{|c|c|c|c|c|c|}
\hline \# & Search terms & Times cited & Relevant hits & Cumulative relevant hits & (New) Relevant references \\
\hline I & Baad-Hansen (2007) & 0 & & & \\
\hline 2 & Aristeguieta (2006) & 0 & & & \\
\hline 3 & Wright (2006) & 0 & & & \\
\hline 4 & Jokstad (2005) & 3 & I & $\mathrm{I}$ & [22] \\
\hline 5 & Magnusson (2004) & 5 & 2 & 2 & {$[10]$} \\
\hline 6 & Shankland WE (2002) & N.N. & & & \\
\hline 7 & Shankland WE (200I) & N.N. & & & \\
\hline
\end{tabular}

Search strategy and results (search date: December 3I, 2007). N.N.: nomen nescio (unknown author)

Table 10: Hierarchy of strength of evidence for therapeutic decisions [slightly modified after [14]]

\begin{tabular}{|c|c|}
\hline Level & Description \\
\hline I & Systematic review of randomized controlled trials (RCTs) \\
\hline II & Article about an RCT \\
\hline III & Article about an experimental study without randomization; cohort study; case-control-study \\
\hline IV & Article about a non-experimental study (cross-sectional study; case series; case report) \\
\hline $\mathrm{V}$ & $\begin{array}{l}\text { Narrative review or expert opinion } \\
\text { (based on clinical experience) without explicit clinical appraisal (e.g., statements, editorials; expert commentaries to published articles; } \\
\text { interviews with experts, brief references to NTI-tss in articles; commercial-like reviews) }\end{array}$ \\
\hline
\end{tabular}

Table I I: Determination of the quality score proposed by Jadad et al [15]

Articles are assessed according to the following questions:

- Was the study described as randomized?

- Was the study described as double blind?

- Was there a description of withdrawals and dropouts? (The number and the reasons for withdrawal in each group must be stated. If there were no withdrawals, it should be stated in the article.)

A score of I point is given for each "yes," a score of 0 points is given for each "no."

- One additional point is given if for question I the method to generate the sequence of randomization was described and it was appropriate (i.e., if it allowed each study participant to have the same chance of receiving each intervention and the investigators could not predict which treatment was next).

- One additional point is given if for question 2 the method of double blinding was described and it was appropriate (i.e., if it is stated that neither the person doing the assessments nor the study participant could identify the intervention being assessed, or in the absence of such a statement the use of active placebos, identical placebos, or dummies is mentioned).

- One point is deducted if for question I the method to generate the sequence of randomization was described and it was inappropriate (e.g., patients were allocated alternately).

- One point is deducted if for question 2 the method of double-blinding was described and it was inappropriate. 
Table I 2: NTI-tss-related websites. Results

\begin{tabular}{lccc}
\hline Web link & Relevant hits & Cumulative relevant hits & Reference/Title \\
\hline http://www.nti-tss.com & 8 & 8 & {$[10,16,22,23,26,48,73,74]$} \\
http://www.ntiamericas.com & 3 & 11 & {$[6,75,76]$} \\
http:/www.nti-tss.com.br/artigos.htm & 9 & 16 & {$[25,77-80]$} \\
http://www.e-motion.eu.com/index.php?name=patients de & 4 & 18 & {$[17,81]$} \\
\hline
\end{tabular}

In addition, a specific search in the FDA's Manufacturer and User Facility Device Experience Database (MAUDE) was carried out with the following strategy: Go to Simple Search $\rightarrow$ Search term: NTI; Date Report Received by FDA: ALL YEARS

\section{Results \\ Overall yield of the search}

A total of 68 relevant publications of different levels of evidence were identified. Details about the search results in the nine electronic databases as well as in the NTI-tssrelated websites are shown in Tables 1 to 9 and 12, respectively. Figure 3 (right column) reveals by which search strategy the publications were found: only 39 contributions were identified by the search in electronic databases and websites.

\section{Qualitative analysis}

The overall qualitative distribution of the relevant publications according to their strength of evidence is shown in Figure 4. Figure 3 provides detailed information about the allocation of the identified 68 articles into the different levels of evidence.

While no systematic review of RCTs (level I) could be identified, 13 contributions reported about the results of clinical studies. Nine of these publications [9,10,16-22] referred to 5 RCTs (level II). Seven of the nine publications about RCTs were published in dental journals; one was a congress abstract [19], and another one was a doctoral thesis [21]. Except the thesis, which was written in Turkish, and a Norwegian article [20], the papers were published in English. The allocation according to the Jadad scale is shown in Table 13.

Among the four publications allotted to level III, there were three congress abstracts [23-25] and one article [26] about an uncontrolled clinical investigation. Twelve contributions referring to 11 case reports were categorized into level IV.

Forty-three publications were classified to level V, representing narrative reviews, editorials, NTI-specific reviews, brief references to NTI-tss in articles, expert commentaries, and interviews.

\section{Contents-based analysis of the articles on RCTs}

The methods and results of the five RCTs are summarized in Tables 14 to 18 . In four studies $[9,10,21,22]$, a complete-arch, hard acrylic resin occlusal stabilization (i.e. non-repositioning) appliance, which was worn at night, was used as therapeutic comparison (Tables 14, 15, 16, 17). In the other trial [18], a full-coverage occlusal splint similar to a bleaching tray was chosen; it was used at night and during stressful periods during wakefulness. Two RCTs focused on electromyographic (EMG) investigations of jaw-closing muscles: In one trial, participants were diagnosed with TMDs and concomitant bruxism [22] (Jadad score: 4); in the other study, the only inclusion criterion was bruxism (and associated symptoms) [21] (Jadad score: 2). In both investigations, the NTI-tss device, but not the occlusal stabilization appliance, showed a significant reduction of the EMG activity. A decrease in clinical symptoms and signs (i.e., pain; number of muscles with tenderness upon palpation; maximum unassisted jaw opening) could not be observed [22].

Two RCTs investigated clinical variables in TMD patients. One of these trials [10] (Jadad score: 5) found no difference between these two devices, while in the other study [9] (Jadad score: 3) a stabilization appliance led to a greater improvement than an NTI-tss device. However, only descriptive statistics were provided in the latter study report. In one RCT [18] (Jadad score: 1), patients with migraine or tension-type headache responded more favorably to the therapy with an NTI-tss device than with a bleaching tray-like splint.

\section{Complications/side effects related to the NTI-tss-device}

While no incidents occurred in the RCTs of Baad-Hansen et al [22] and Shankland [16-18], complications or side effects were observed in the other three RCTs [22] (Table $19)$. Two more incidents $[13,27]$ were identified in the reference lists of Magnusson et al [9] and Jokstad et al [10], respectively, while one report was found in a book chapter [2]. Finally, five cases were published in the FDA Medical Device reporting website (Table 20).

Different complications and side effects were documented; however, no case of an aspiration could be found. 


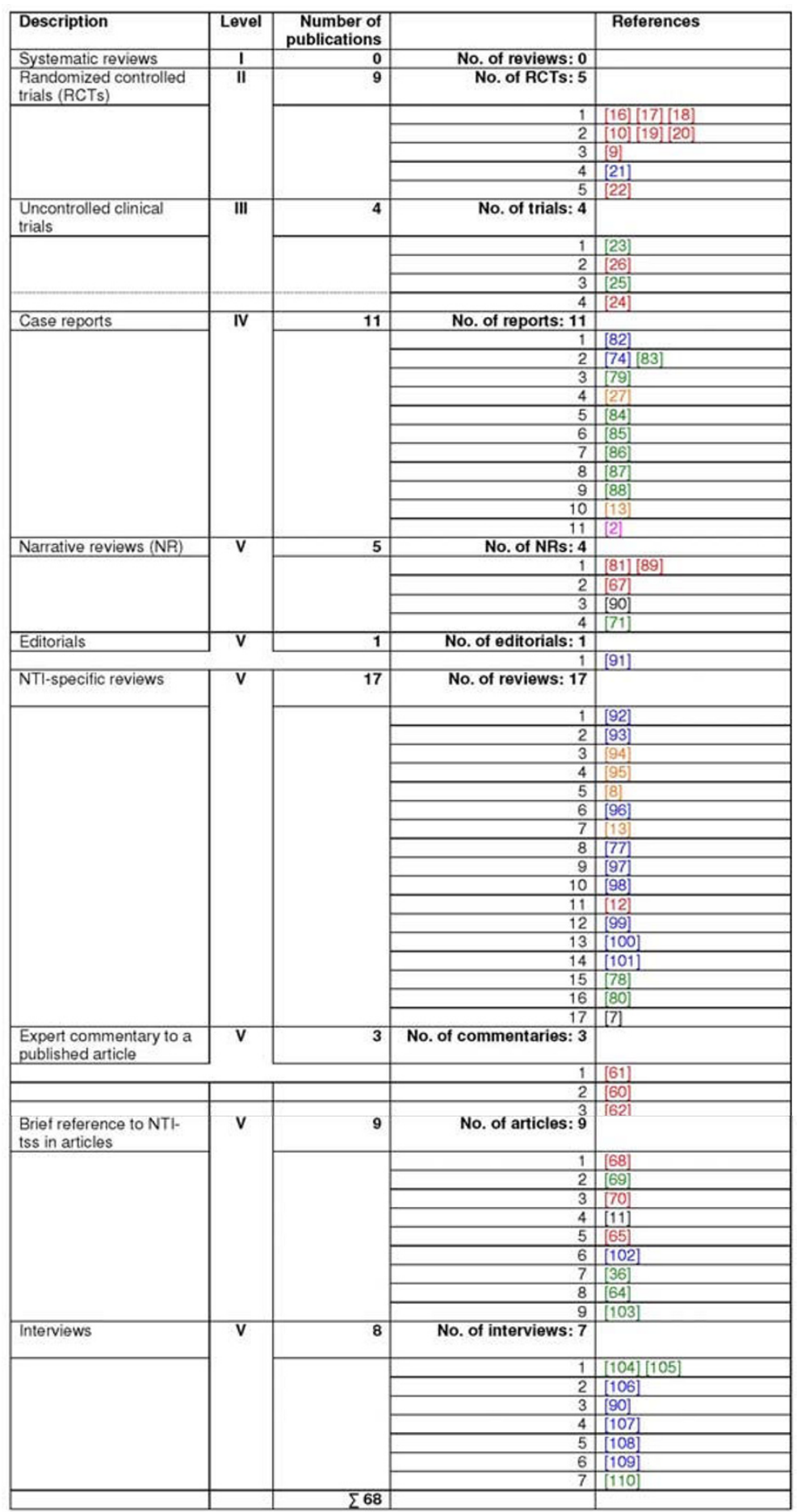

\section{Figure 3}

Allocation of the identified 68 articles according to the hierarchy of strength of evidence. Red: hits in electronic databases $(n=20)$; green: publications identified by searching the websites $(n=19)$; orange: articles found in the reference lists of identified articles $(n=6)$; purple: contributions found in textbooks $(n=1)$; blue: publications mailed by providers of the NTItss device $(n=19)$; black: publications found in other sources $(n=3)$. 


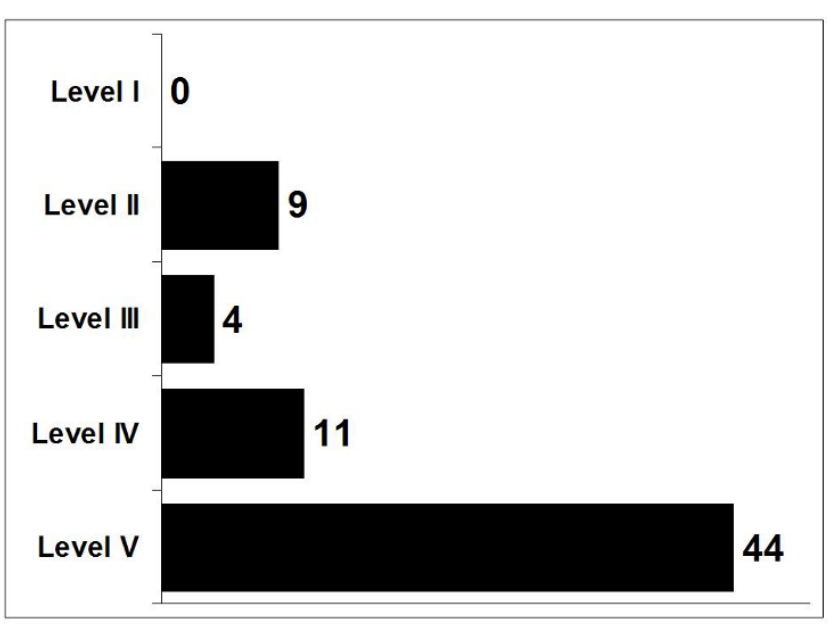

\section{Figure 4}

Qualitative distribution of the identified publications according to the strength of evidence (cf. Table I).

\section{Discussion}

We were surprised to find that within the past decade as much as nine different trials related to the NTI-tss device were carried out, five of which were RCTs, while four were uncontrolled investigations [23-26] (Figure 1). As far as the estimation of the efficacy of a therapeutic measure is concerned, it is wise to consider primarily (or exclusively [28]) articles about RCTs, because they provide the strongest evidence on the efficacy of a therapy [29,30]. Numerous examples have shown that observational studies, as compared to RCTs, are likely to generate over-optimistic (i.e., false-positive) conclusions [31-33]. Hence, it is not surprising that in clinical trials without control group the NTI-tss device was reported to be associated with a marked decrease in patients suffering from headache [25] and TMD-associated otologic symptoms (vertigo; otalgia; otic fullness; tinnitus; subjective hearing loss) [26].
In the five RCTs, which evaluated clinical and electromyographic effects of the NTI-tss device, different inclusion criteria and methods were used. Therefore, the results had to be analyzed separately. Each RCT has methodological weaknesses. Four studies had a limited number of participants ( $\mathrm{n}=10$ to 38 ) (cf. Tables $14,15,16,17,18)$, which may have resulted in a statistical type II error (erroneous acceptance of the null hypothesis), as noted by Jokstad et al [10]. Shankland's investigation, in contrast, included 94 patients [18]; however, study and reporting quality were limited. The methodological flaws inherent to this study are not only reflected by the low Jadad score of 1 , but also by the shortcoming to distinguish between the diagnoses of migraine and tension-type headache, which are completely different entities [34]. Shankland excluded patients with TMDs; however, there is a considerable symptom overlap between headache and TMD patients [35]. In fact, the same patient who suffers from pain in the temples may be diagnosed as having tension-type headache by a neurologist, whereas she may be diagnosed with myofascial pain in the temporal muscles by a dentist. Hence, an exact differential diagnosis between the two entities appears to be nearly impossible. Furthermore, there are limitations associated with the statistical analysis of the data gained in this study; for example, no information was provided about pre-treatment days of headache in that study [36].

Focusing on the identified articles about RCTs, two main indications for the NTI-tss splint may be distinguished: bruxism and TMDs. As far as bruxism is concerned, the studies of Baad-Hansen et al [22] and Kavaklı [21] have shown that - when compared to baseline EMG recordings from the masseter muscle during sleep - insertion of the NTI-tss device leads to a significant reduction in EMG activity of jaw closing muscles during clenching or grinding. These findings are compatible with early results from Van Eijden et al [37] who found that maximal effort clenches on the incisal edges of the incisors resulted in a

Table 13: Assessment of the quality of the articles about randomized controlled trials (RCTs) according to the quality score proposed by Jadad et al [15]

\begin{tabular}{|c|c|c|c|c|c|c|}
\hline Study & $\begin{array}{l}\text { Study described } \\
\text { as randomized? }\end{array}$ & $\begin{array}{l}\text { Method described } \\
\text { and appropriate? }\end{array}$ & $\begin{array}{l}\text { Study described } \\
\text { as blind? }\end{array}$ & $\begin{array}{l}\text { Method described } \\
\text { and appropriate? }\end{array}$ & $\begin{array}{l}\text { Description of } \\
\text { withdrawals/ } \\
\text { dropouts? }\end{array}$ & Jadad score \\
\hline $\begin{array}{l}\text { Baad-Hansen et } \\
\text { al [22] }\end{array}$ & Yes & Not described & Yes & Yes & $\begin{array}{c}\text { No withdrawals or } \\
\text { dropouts }\end{array}$ & 4 \\
\hline Kavaklı [2I] & Yes & Not described & No & --- & $\begin{array}{c}\text { No withdrawals or } \\
\text { dropouts }\end{array}$ & 2 \\
\hline $\begin{array}{l}\text { Jokstad et al } \\
{[10,20]}\end{array}$ & Yes & Yes & Yes & Yes & Yes & 5 \\
\hline $\begin{array}{l}\text { Magnusson et al } \\
\text { [9] }\end{array}$ & Yes & Yes & No & --- & Yes & 3 \\
\hline Shankland $[16,18]$ & Yes & Not described & No & --- & No & 1 \\
\hline
\end{tabular}


Table 14: Characteristics of the study of Baad-Hansen et al [22]

\begin{tabular}{|c|c|c|c|c|c|c|c|}
\hline Study & Type of study & Aim of the study & $\begin{array}{l}\text { Patient } \\
\text { recruitment }\end{array}$ & Inclusion criteria & Exclusion criteria & $\mathbf{n}$ & $\begin{array}{l}\text { Therapeutic } \\
\text { comparison }\end{array}$ \\
\hline \multirow[t]{4}{*}{ Baad-Hansen et al [22] } & $\begin{array}{l}\text { Investigator-blinded } \\
\text { randomized } \\
\text { controlled cross-over } \\
\text { trial }\end{array}$ & $\begin{array}{l}\text { I. To compare the } \\
\text { therapeutic efficacy of } \\
\text { two different intraoral } \\
\text { devices on the EMG } \\
\text { activity of bruxers } \\
\text { during sleep. }\end{array}$ & $\begin{array}{l}\text { Self-presentation of } \\
\text { patients at the School } \\
\text { of Dentistry, } \\
\text { University of Aarhus } \\
\text { (Denmark) }\end{array}$ & $\begin{array}{l}\text { I. Self-reported tooth- } \\
\text { grinding during sleep, } \\
\text { confirmed by bed- } \\
\text { partner. }\end{array}$ & $\begin{array}{l}\text { Use of any other } \\
\text { medication than mild } \\
\text { analgesics }\end{array}$ & $\begin{array}{l}10 \text { (average age: not } \\
\text { reported; range: } 23- \\
39 \text { years) }\end{array}$ & $\begin{array}{l}\text { NTI-tss device }(n= \\
\text { 10) vs. flat occlusal } \\
\text { stabilization splint } \\
\text { (OS) }(n=10) \text { worn at } \\
\text { night }\end{array}$ \\
\hline & & & & $\begin{array}{l}\text { 2. Reports of muscle } \\
\text { soreness on } \\
\text { awakening. }\end{array}$ & & & \\
\hline & & & & 3. Signs of tooth wear. & & & \\
\hline & & $\begin{array}{l}\text { 2. To evaluate if } \\
\text { changes in EMG } \\
\text { activity are associated } \\
\text { with short-term } \\
\text { changes in TMD- } \\
\text { related pain. }\end{array}$ & & $\begin{array}{l}\text { 4. TMD diagnosis by a } \\
\text { blinded investigator } \\
\text { according to the RDC/ } \\
\text { TMD [ I I I I]. }\end{array}$ & & & \\
\hline Study & Study duration & $\begin{array}{l}\text { Outcome } \\
\text { parameters }\end{array}$ & Results & & & Authors' conclusior & \\
\hline \multirow[t]{10}{*}{ Baad-Hansen et al [22] } & 7-8 weeks & $\begin{array}{l}\text { I. "A strong and } \\
\text { lasting inhibition of } \\
\text { EMG activity in } \\
\text { masseter muscles } \\
\text { during sleep was } \\
\text { caused by wearing the } \\
\text { NTI splint but not the } \\
\text { OS. However, this } \\
\text { was not directly } \\
\text { related to the short- } \\
\text { term clinical outcome } \\
\text { measures." }\end{array}$ & \multicolumn{3}{|c|}{ Within-treatment-group pre-post differences } & \multirow{10}{*}{\multicolumn{2}{|c|}{$\begin{array}{l}\text { "A strong and lasting inhibition of EMG activity } \\
\text { in masseter muscles during sleep was caused by } \\
\text { wearing the NTI splint but not the OS. } \\
\text { However, this was not directly related to the } \\
\text { short-term clinical outcome measures }\end{array}$}} \\
\hline & & & \multirow{2}{*}{\multicolumn{3}{|c|}{$\begin{array}{l}\text { NTI-tss group: } \\
\text { - Significant decreases at all levels of EMG threshold during the use of the } \\
\text { NTI-tss device when compared with baseline. }\end{array}$}} & & \\
\hline & & & & & & & \\
\hline & & & \multicolumn{3}{|c|}{$\begin{array}{l}\text { OS group: } \\
\text { - No differences between the baseline EMG values for any of the EMG } \\
\text { measures. }\end{array}$} & & \\
\hline & & & \multicolumn{3}{|c|}{ Between-groups post-treatment differences } & & \\
\hline & & & \multirow{2}{*}{\multicolumn{3}{|c|}{$\begin{array}{l}\text { EMG outcomes: } \\
\text { In contrast to the OS, the NTI-tss device was associated with significant } \\
\text { decreases when compared with EMG baseline values. }\end{array}$}} & & \\
\hline & & & & & & & \\
\hline & & & \multicolumn{3}{|l|}{ Clinical outcomes: } & & \\
\hline & & & \multicolumn{3}{|c|}{ - No differences between the two therapies } & & \\
\hline & & & \multicolumn{3}{|c|}{ - No significant correlations between EMG data and clinical variables. } & & \\
\hline
\end{tabular}


Table 15: Characteristics of the study of Kavaklı [2I]

\begin{tabular}{|c|c|c|c|c|c|c|c|}
\hline Study & Type of study & Aim of the study & Patient recruitment & Inclusion criteria & Exclusion criteria & $\mathbf{n}$ & $\begin{array}{l}\text { Therapeutic } \\
\text { comparison }\end{array}$ \\
\hline \multirow[t]{8}{*}{ Kavaklı [2I] } & $\begin{array}{l}\text { Randomized } \\
\text { controlled trial }\end{array}$ & $\begin{array}{l}\text { To compare the } \\
\text { therapeutic efficacy of two } \\
\text { different intraoral devices } \\
\text { on the EMG activity of } \\
\text { bruxers during sleep. }\end{array}$ & $\begin{array}{l}\text { Self-presentation at the } \\
\text { Hacettepe University } \\
\text { Health Science Institute, } \\
\text { Ankara (Turkey) }\end{array}$ & $\begin{array}{l}\text { I. Self-reported tooth } \\
\text { clenching and tooth } \\
\text { grinding for at least } 6 \\
\text { month }\end{array}$ & $\begin{array}{l}\text { I. More than two } \\
\text { missing molars }\end{array}$ & $\begin{array}{l}20 \text { (average age: } 31 \\
\text { years; range: } 14-52 \\
\text { years) }\end{array}$ & $\begin{array}{l}\text { NTI-tss device }(n=11) \\
\text { vs. Michigan- type } \\
\text { stabilization splint }(\mathrm{SS})(\mathrm{n} \\
=9) \text { worn at night }\end{array}$ \\
\hline & & & & $\begin{array}{l}\text { 2. Grinding sounds } \\
\text { during sleep for at least } \\
3 \text { nights per week as } \\
\text { confirmed by bed- } \\
\text { partner }\end{array}$ & $\begin{array}{l}\text { 2. Removable } \\
\text { prosthetic } \\
\text { restoration }\end{array}$ & & \\
\hline & & & & 3. Jaw muscle discomfort & 3. Gross malocclusion & & \\
\hline & & & & 4. Abnormal tooth wear & $\begin{array}{l}\text { 4. Constant use of } \\
\text { sleep medication }\end{array}$ & & \\
\hline & & & & 5. Masseter hypertrophy & $\begin{array}{l}\text { 5. Abuse of alcohol } \\
\text { and/or drugs }\end{array}$ & & \\
\hline & & & & $\begin{array}{l}\text { 6. Diagnosis of sleep } \\
\text { bruxism in a sleep } \\
\text { laboratory }\end{array}$ & $\begin{array}{l}\text { 6. Neurological or } \\
\text { psychological diseases }\end{array}$ & & \\
\hline & & & & & 7. Sleeping disorders & & \\
\hline & & & & & $\begin{array}{l}\text { 8. Internal TMJ } \\
\text { derangements as } \\
\text { diagnosed with an } \\
\text { MRI }\end{array}$ & & \\
\hline
\end{tabular}

\begin{tabular}{llll}
\hline Study duration & Outcome parameters & Results & Authors' conclusions \\
\hline 4 months & (A) Sleep variables: & $\begin{array}{l}\text { Within-treatment-group pre- post } \\
\text { differences }\end{array}$ & $\begin{array}{l}\text { I. Both splint designs do not stop sleep bruxism } \\
\text { activity as shown by polysomnographic } \\
\text { evaluation. }\end{array}$
\end{tabular}


Table 15: Characteristics of the study of Kavaklı [2I] (Continued)

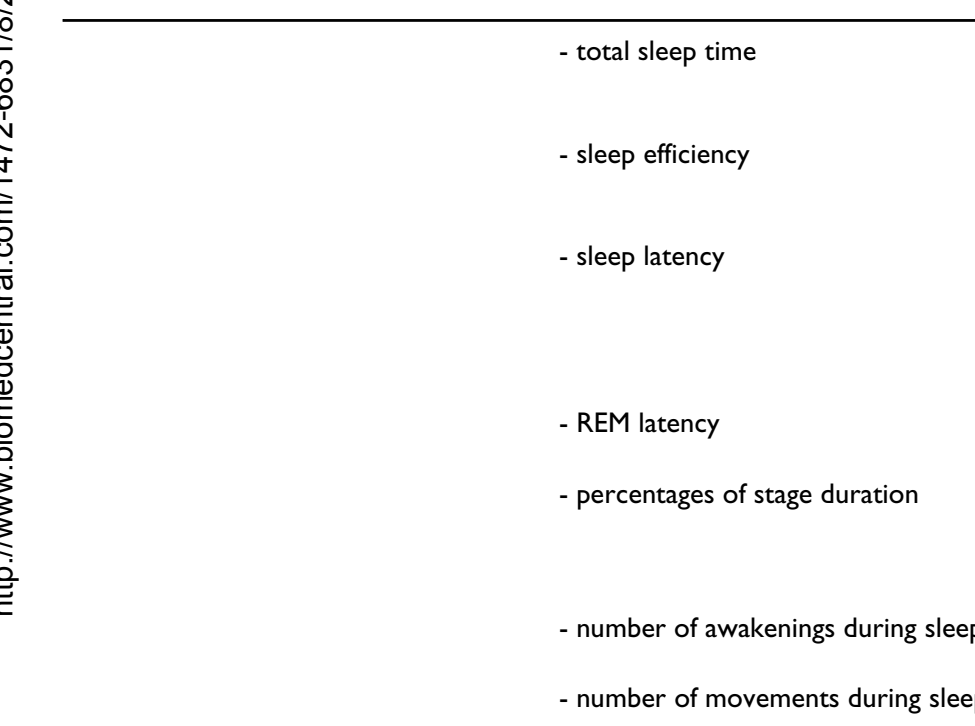

(B) Respiratory variables:

- apnea

- hypoapnea

(C) Bruxism-related variables as derived from masseter and temporal muscle activity:

- total bruxism duration

- number of bruxism episodes/night

- number of bruxism episodes/h

- number of bruxism burst/episode

- number of bruxism burst/h

- amplitude of bruxism episodes
NTI-tss device:

- no changes of other sleep parameters

- no changes of respiratory parameters

no changes in occlusion

- reduced intensity of masseter and temporalis muscles contraction activities compared to baseline

\section{Stabilization splint:}

- sleep stage 2 was shorter as compared to baseline

- no changes of other sleep parameters

- no changes of respiratory parameters

- no changes of sleep bruxism activity

\section{Between-groups post- treatment}

differences

No changes
2. The SS does not reduce the frequency,

duration or intensity of the sleep bruxism.

3. The NTI-tss device reduces the intensity of bruxism.

4. Due to its positive effect on sleep bruxism and its easy adapatability, the NTI-tss device is

recommended if regular check-ups by a dentist are possible. 
Table 16: Characteristics of the study of Jokstad et al $[10,19,20]$

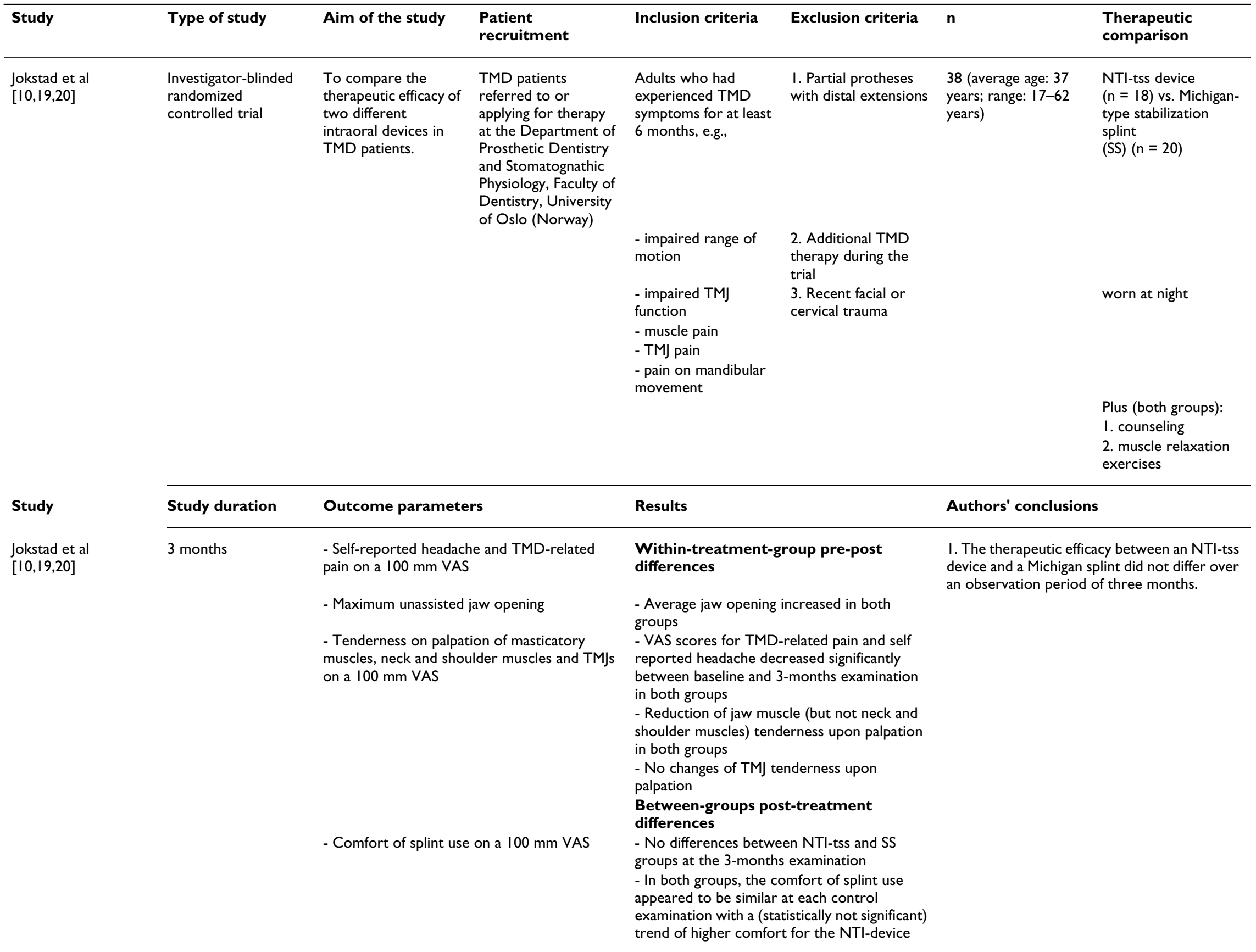


Table 17: Characteristics of the study of Magnusson et al [9]

\begin{tabular}{|c|c|c|c|c|c|c|c|}
\hline Study & Type of study & Aim of the study & $\begin{array}{l}\text { Patient } \\
\text { recruitment }\end{array}$ & Inclusion criteria & Exclusion criteria & $\mathbf{n}$ & $\begin{array}{l}\text { Therapeutic } \\
\text { comparison }\end{array}$ \\
\hline \multirow[t]{8}{*}{ Magnusson et al [9] } & $\begin{array}{l}\text { Investigator-blinded } \\
\text { randomized } \\
\text { controlled trial }\end{array}$ & $\begin{array}{l}\text { To compare the } \\
\text { therapeutic efficacy of } \\
\text { two different } \\
\text { intraoral devices in } \\
\text { TMD patients. }\end{array}$ & $\begin{array}{l}\text { Patients referred for } \\
\text { suspected TMDs to } \\
\text { the Department of } \\
\text { Stomatognathic } \\
\text { Physiology, the } \\
\text { Institute for } \\
\text { Postgraduate Dental } \\
\text { Education, Jönköping } \\
\text { (Sweden) }\end{array}$ & $\begin{array}{l}\text { 1. TMD symptoms } \geq \\
6 \text { months }\end{array}$ & $\begin{array}{l}\text { I. Ongoing TMD } \\
\text { therapy }\end{array}$ & $\begin{array}{l}28 \text { (average age: } 31.5 \\
\text { years; range: 16-70 } \\
\text { years) }\end{array}$ & $\begin{array}{l}\text { NTI-tss device } \\
(\mathrm{n}=14) \text { vs. Michigan- } \\
\text { type stabilization } \\
\text { splint }(\mathrm{SS})(\mathrm{n}=14) \\
\text { worn at night }\end{array}$ \\
\hline & & & & 2. Age: $\geq 16$ years & $\begin{array}{l}\text { 2. Therapy with any } \\
\text { kind of interocclusal } \\
\text { appliance during the } \\
\text { past year }\end{array}$ & & \\
\hline & & & & $\begin{array}{l}\text { 3. } \geq 12 \text { teeth both in } \\
\text { the upper and lower } \\
\text { jaw }\end{array}$ & $\begin{array}{l}\text { 3. TMD symptoms } \\
\text { and signs justifiying } \\
\text { another initial therapy } \\
\text { than an interocclusal } \\
\text { appliance }\end{array}$ & & \\
\hline & & & & $\begin{array}{l}\text { 4. Moderate or } \\
\text { severe clinical signs } \\
\text { according to } \\
\text { Helkimo's Clinical } \\
\text { Dysfunction Index }\end{array}$ & $\begin{array}{l}\text { 4. Anterior teeth with } \\
\text { periodontitis or fixed } \\
\text { partial dentures }\end{array}$ & & \\
\hline & & & & $\begin{array}{l}\text { 5. Pronounced } \\
\text { subjective symptoms } \\
\text { according to } \\
\text { Helkimo's } \\
\text { Anamnestic Index }\end{array}$ & $\begin{array}{l}\text { 5. Pronounced pre- } \\
\text { or postnormal } \\
\text { occlusion }\end{array}$ & & \\
\hline & & & & $\begin{array}{l}\text { 6. Frequent tension- } \\
\text { type headache }\end{array}$ & 6. Deep bite & & \\
\hline & & & & & 7. Psychic disorder & & \\
\hline & & & & & 8. Language difficulties & & \\
\hline
\end{tabular}

\section{Within-treatment-group pre-post} improvement

6-month follow-up of the NTI-group $(n=10)$ :
1. "The almost $100 \%$ treatment success that have been claimed after NTI treatment could not be confirmed in this study."

- Deviation/deflectio

"The statement of a gain in chair-side time with the NTI device can be questioned. The use of NTI devices, however, eliminates one clinical visit, as well as the laboratory costs." 
- $\mathrm{n}$ on jaw

- opening

- TMJ sounds

- Pain on mandibular movement

- Muscle/TMJ pain upon palpation

- Number of occluding teeth

- Time for impression-taking, interocclusal recording and adjustment of stabilization splint

- Time for fitting and adjustment of the NTItss device

- Adherence to the allocated splint

- Use of analgetics

- Symptom intensity (6-point behavior scale, II-point numerical scale)
- significant improvement $(n=6)$

- some improvement $(n=I)$

- no change $(n=2)$

- impairment $(\mathrm{n}=\mathrm{I})$

- impaired occlusion $(n=1)$

- decreased use of analgetics

$(\mathrm{n}=2)$

- increased use of analgetics $(n=2)$

- 6-point behavior scale: $3.4 \rightarrow 2$. 1

- II-point numerical scale: $5.9 \rightarrow 3.8$

6-month follow-up of the SS-group $(n=14)$ :

- significant improvement $(n=12)$

- some improvement $(n=2)$

- decreased use of analgetics

$(\mathrm{n}=10)$

- 6-point behavior scale: $3.4 \rightarrow 1.9$

- II-point numerical scale: $5.9 \rightarrow 3.3$

\section{Between-groups post-treatment}

differences

- 3-month follow-up: 4 patients with NTI-tss device changed to SS due to impairment or no improvement of their symptoms, while none of the SS users changed the group.

- For all variables, improvement was larger in the SS-group than the NTI-group

- SS-appliances were judged to be more comfortable than the NTI-tss device

Mean production time

- NTI-tss device: 27 minutes

SS: 17 minutes

3. "It can not be ruled out that long time use of NTI splints can be detrimental for the

occlusion."

"All of the studied variables were in favour for the stabilization splint, compared to the NTI device." 
Table 18: Characteristics of the study of Shankland $[16,18]$

\begin{tabular}{|c|c|c|c|c|c|c|c|}
\hline Study & Type of study & Aim of the study & $\begin{array}{l}\text { Patient } \\
\text { recruitment }\end{array}$ & Inclusion criteria & Exclusion criteria & $\mathbf{n}$ & $\begin{array}{l}\text { Therapeutic } \\
\text { comparison }\end{array}$ \\
\hline Shankland $[16,18]$ & $\begin{array}{l}\text { Randomized } \\
\text { controlled clinical } \\
\text { trial }\end{array}$ & $\begin{array}{l}\text { To evaluate the safety } \\
\text { and effectiveness of } \\
\text { the NTI-tss device for } \\
\text { the reduction of } \\
\text { frequency and } \\
\text { severity of tension- } \\
\text { type and migraine } \\
\text { headaches. }\end{array}$ & Not reported & $\begin{array}{l}\text { I. Diagnosis of } \\
\text { tension-type or } \\
\text { migraine headaches }\end{array}$ & Presence of TMDs & $\begin{array}{l}94 \text { (average age and } \\
\text { range: not reported) }\end{array}$ & $\begin{array}{l}\text { NTI-tss device } \\
(\mathrm{n}=5 \mathrm{I}) \text { vs. full- } \\
\text { coverage occlusal } \\
\text { splint without cuspid } \\
\text { rise and anterior } \\
\text { guidance (similar to a } \\
\text { bleaching tray) ( } \mathrm{n}= \\
\text { 43) worn at night and } \\
\text { during the day when } \\
\text { perceiving stressful } \\
\text { periodes }\end{array}$ \\
\hline
\end{tabular}

2. Intake of

periodes

Sumatriptan as a

rescue medication

3. 3. Having

experienced an

average of two

migraine episodes or

8 tension-type

headaches per month

4. Presence of natural

or fixed prosthetic

maxillary and natura

mandibular incisors

5. Overbite and

overjet within normal

limits

6. Stable dentition

with no current

orthodontic

treatment and fully

erupted teeth

7. No significant

periodontal disease

8. No TMD signs and/

or symptoms

9. At least 18 years of

age 
Table 18: Characteristics of the study of Shankland [16,18] (Continued)

- Interocclusal record

- Tooth mobility of all anterior teeth

- Tooth sensibility of the anterior teeth (temperature, pressure)

- Periodontal health of all teeth

- Periapical radiographs of the anterior teeth

- Vitality of the anterior teeth

- Tenderness of the head and neck muscles

- Trigger points

- Range of mandibular motion

\section{- TMJ noises}

- TMJ tenderness

- Tension-type headache

- Migraine headache

- Nausea

- Photophobia

- Phonophobia

- Analgesics taken (and doses)

- Use of rescue medicine (Sumatriptan ${ }^{\circledR}$ )

(B) Clinical subjective outcomes (VAS):

- Intensity of tension-type headache

- Intensity of migraine
Results

Within-treatment-group pre-post

differences

\section{NTI-tss group:}

$-16 \%$ of the participants reported an $85 \%$ to $100 \%$ reduction of migraine headaches

Users reported an elimination of $46.9 \%$ of all

headache pain as well as reduction of

photophobia, phonophobia and nausea

Control group:

$7 \%$ of the subjects reported a $85 \%$ to $100 \%$ reduction of migraine headaches

- $27 \%$ of the subjects reported an average $46 \%$ increase in migraine events

- Increase of migraine frequency

\section{Between-groups post-treatment}

\section{differences}

- In every category (headache episodes, dosages of rescue medicine (Imitrex ${ }^{\circledR}$ ), phonophobia, photophobia, nausea), the percentage of reduction of all symptoms decreased for those in the NTI-tss group.
Authors' conclusions

I. "The NTI-tss appliance proved safe an efficacious in the reduction of medically diagnosed migraine and tension-type

headache." 
Table 19: Complications and side effects associated with the use of the NTI-tss device as described in the identified publications

\begin{tabular}{|c|c|}
\hline Study & Complications/Side effects \\
\hline Clark \& Minakuchi [2] & - Anterior open bite induced after wearing the device 24 hours a day over an extended period of time $(n=1)$ \\
\hline Kavaklı [2I] & - Radiologically diagnosed widened periodontal ligament plus alveolar bone resorption in one tooth $(n=1 / 20)$ \\
\hline \multirow[t]{5}{*}{ Jokstad et al [10] } & - Sensitive lower front teeth $(n=1 / 18)$ \\
\hline & - Dryness of the mouth while sleeping $(n=6 / 18)$ due to a forced open jaw caused by the NTI-tss design \\
\hline & - Swallowing difficulties $(n=2 / / 8)$ \\
\hline & - The protruding tip of the device was felt to be annoying $(n=1 / 18)$ \\
\hline & - The device was falling out or being taken out unconsciously while sleeping $(n=2 / 18)$ \\
\hline \multirow[t]{3}{*}{ Magnusson et al. [9] } & $\begin{array}{l}\text { - Altered occlusion between the } 3 \text { - and 6-month follow-up: "the vertical overbite decreased with one millimeter, and the } \\
\text { number of occluding tooth pairs was reduced from } 10 \text { to } 15 \text { " }(n=1 / 14)\end{array}$ \\
\hline & - Transient tenderness in the teeth when the device was used $(n=6 / 14)$ \\
\hline & - Tongue thrusting, dry mouth, increased salivation, snoring (as reported by "single patients") \\
\hline Fleten \& Gjerdet [13] & - Swallowing of an NTI-tss device, which was lodged at the esophageal entrance $(n=1)$ \\
\hline \multirow[t]{2}{*}{ Fitins [27] } & - Sensitive and painful maxillary central incisor $(n=1)$ \\
\hline & - Moderate mobility of and local bone loss around three maxillary incisors \\
\hline
\end{tabular}

significant decline of EMG activity as compared to clenching in intercuspation.

The fact that Baad-Hansen et al [22] were unable to correlate their EMG findings with clinical symptoms (e.g., reduction of reported pain) may be due to the short duration of wearing the intraoral device (2 weeks). Data from other investigations suggests that a decrease of EMG activ- ity may indeed be associated with a pain reduction in patients with masticatory muscle pain [38]. Moreover, a decrease of EMG activity is not a unique characteristic of the NTI-tss device, but may be achieved with any anterior bite stop [39], sometimes even with a full-coverage occlusal appliance [38]. Hence, we concur with Clark and Minakuchi [2] who suggest in their recent review on oral appliances that it is "reasonable to use a partial-coverage

Table 20: Complications and/or side effects as described in the MAUDE database

\begin{tabular}{|c|c|c|}
\hline Web link & Year & Complaints/Side effects \\
\hline $\begin{array}{l}\text { http://www.accessdata.fda.gov/scripts/cdrh/cfdocs/cfMAUDE/ } \\
\text { Detail.CFM?MDRFOI ID=47/018 }\end{array}$ & 2003 & $\begin{array}{l}\text { "This device }[. . .] \text { will not stop migraines, it took out pt's two front crown } \\
\text { teeth, it causes tooth movement, joint strain }[\ldots . .] \text {. This device is harmful - } \\
\text { dangerous and it is not therapeutic. Pt had to have surgery to undo the } \\
\text { harm that was caused by the nti splint" }\end{array}$ \\
\hline $\begin{array}{l}\text { http://www.accessdata.fda.gov/scripts/cdrh/cfdocs/cfMAUDE/ } \\
\text { Detail.CFM?MDRFOI ID=55/955 }\end{array}$ & 2004 & $\begin{array}{l}\text { "[...] the device was not only ineffective, but has done damage to their jaw } \\
\text { alignment, bite, and facial appearance. The device caused them to grind } \\
\text { their front teeth instead of their molars. Even though rptr only wore it for } \\
\text { two weeks, rptr's jaw and their bite has not returned to "normal". During } \\
\text { the two weeks rptr wore it, rptr suffered extreme headaches, facial pain, } \\
\text { and their front teeth loosened. [...] Rptr's teeth are actually moving position } \\
\text { since rptr can barely bite down without forcing their lower jaw back. Their } \\
\text { front teeth are shifting back because they are constantly pushing against } \\
\text { their upper teeth. Eating and chewing is challenging since they can't actually } \\
\text { touch their upper and lower molars together without effort. Therefore, } \\
\text { rptr's lower jaw spasms when they chew." }\end{array}$ \\
\hline $\begin{array}{l}\text { http://www.accessdata.fda.gov/scripts/cdrh/cfdocs/cfMAUDE/ } \\
\text { Detail.CFM?MDRFOI ID }=557 / 67\end{array}$ & 2004 & $\begin{array}{l}\text { "Pt's concern is that this device poses a significant threat of death by } \\
\text { choking. [...] A user could dislodge the nti-tss with the tongue, or, during } \\
\text { sleep, unconsciously reach into the mouth to loosen or readjust it it is very } \\
\text { uncomfortable-. If it remained in the mouth it could easily become lodged in } \\
\text { the throat." }\end{array}$ \\
\hline $\begin{array}{l}\text { http://www.accessdata.fda.gov/scripts/cdrh/cfdocs/cfMAUDE/ } \\
\text { Detail.cfm?MDRFOI ID }=753670\end{array}$ & 2006 & $\begin{array}{l}\text { "Since the implant was put in, patient has been having migraine headaches } \\
\text { and a clicking jaw. [...] Her teeth have moved so much that according to the } \\
\text { dentist, she would need braces to move her teeth to position. Patient never } \\
\text { had a history of migraine." }\end{array}$ \\
\hline $\begin{array}{l}\text { http://www.accessdata.fda.gov/scripts/cdrh/cfdocs/cfMAUDE/ } \\
\text { Detail.cfm?MDRFOI ID }=765535\end{array}$ & 2006 & $\begin{array}{l}\text { "Not only is his new apparatus devoid of a safety device to keep him from } \\
\text { swallowing it in his sleep, but (I) it fit very tightly and }(2) \text { it was very difficult } \\
\text { to remove. When he did take out the device, it felt as if he was going to pull } \\
\text { his teeth out. Last night, when he went to sleep, he was awakened when } \\
\text { the device broke in his mouth." }\end{array}$ \\
\hline
\end{tabular}


anterior bite appliance in those patients with a known tooth-clenching habit, because this habit cannot be controlled with a stabilization appliance." On the other hand, a hard acrylic resin stabilization splint may be helpful in patients with tooth grinding, because it helps preventing the unwanted consequence of sleep bruxism [40], such as tooth wear (attrition), tooth grinding sounds, and - often - associated pain [41].

Regarding the management of patients with (localized) TMDs (e.g., myofascial face pain and/or arthralgia of the TMJs), the use of stabilization appliances is sufficiently supported by evidence in the dental literature [42-45]. Türp et al [45], for instance, concluded after a systematic review of the literature that most patients with masticatory muscle pain are helped by the incorporation of a stabilization splint. Particularly patients with local pain of the myofascial muscles (as opposed to individuals with widespread pain) are likely to experience improvement from this therapy [46].

Helkimo's statement that there is "no peer-reviewed scientific publication that exhibits that the NTI-splint is superior to other well-established conventional splints for the treatment if [sic] functionally related facial pain or mandibular dysfunction" [8] still holds true: a superiority of this anterior bite stop has not yet been shown. Nonetheless, the currently best available evidence [10] suggests that for the management of TMDs the NTI-tss device is similarly efficacious as a stabilization appliance. This demonstrates, on the other hand, that the observed reduction in clinical symptoms is not a feature unique to the NTI-tss device. Instead, it may also be achieved with other splints, even with other forms of anterior bite stops: Nilner et al [47], for instance, observed in patients suffering from myofascial face pain that at 6 - and 10 -weeks followup appointments a prefabricated appliance covering the six upper front teeth may be as effective in pain improvement as a traditional stabilization appliance. In a patient group with the same diagnosis, Al Quran and Kamal [48] who inserted an NTI-tss-like device (AMPS: anterior midline point stop) reported similar clinical results after 1 month and 3 months.

The positive effect after the incorporation of any type of appliance has frequently been explained by patient-specific behavioral changes [2]. However, such an assumption is hard to justify given the fact that the splints are usually worn at night during sleep, as it was also the case in the RCTs reviewed here. Regarding localized myofascial pain of the masticatory musculature, an alternative explanation is based on the heterogeneous activation capability of these muscles [37,49-51]: Experimental results in healthy volunteers indicate that a temporary positional alteration of the mandible (e.g., an increase of the vertical dimension after insertion of an occlusal appliance) changes the intramuscular recruitment pattern, which is often followed by a pain reduction [52-55]. Although this biomechanical hypothesis needs further studies to be validated [56], it provides a physiologically plausible explanation for the therapeutic success gained with oral splints.

We were unable to find evidence for the statement that the NTI-tss device was indicated for the prevention of bruxism, TMDs, chronic tension-type headaches, migraine, or occlusal trauma. Likewise, due to the poor quality of the publications by Shankland $[16,18,17]$, its use for the therapy of migraine remains doubtful.

Contrary to claims made in the dental literature $[10,12]$, cases of aspirated NTI-tss devices could not be identified in the present review (c.f. Tables 19 and 20). None of the five reports published in the MAUDE database referred to such an event. Fleten and Gjerdet [13], who allegedly reported about an aspiration, presented a case where an NTI-tss splint was lodged at the esophageal entrance.

Nonetheless, possible side effects, particularly those related to the teeth and the occlusion, remain the greatest concern when wearing NTI-tss splints (cf. Table 20). Of course, adverse events may also occur when a stabilization appliance is used. Clark and Minakuchi [2] mention two concerns which, albeit rare, need to be considered in this context: (a) increase of clenching activity when wearing the bite splint; (b) unintended occlusal change after fulltime use, due to alterations of the position of individual teeth or of the mandible. However, if a stabilization appliance is worn at night only - and, if needed (e.g., during stressful periods of life), additionally during one or two hours of the day - the development of an applianceinduced malocclusion is unlikely. Other side effects, such as increased or decreased salivation [57], are usually short-lasting, while tension in the teeth [57] can mostly be eliminated by careful adjustments along the labial and/or buccal surfaces that ensure the retention of the stabilization appliance. Since it is certain that published case reports represent only a fraction of all adverse events that have occurred while using any type of intraoral appliance, clinicians should be encouraged to frankly report any unintended negative outcome associated with splint therapy. In the hierarchy of scientific evidence, case reports represent a low level (cf. Table 9). Nonetheless, considering the absence of other data we believe that the publications summarized in Tables 19 and 20 deliver valuable information and convey an important message to the clinician (as well as to the patient), namely that the use of the device is not fee of risks. Unfortunately, no risk quantification is possible at this point in time. Meanwhile, it remains crucial to take care that a patient receiving an NTI-tss device remains compliant with follow-up 
appointments, especially when wearing it over an extended period of time.

It has been argued that an advantage of the NTI-tss splint as compared to a conventional occlusal bite splint is the reduced chair-side time. Therefore, some dentists are likely to be surprised when confronted with Magnusson et al's report [9] that on the average 27 minutes (range: 1745 minutes) were needed to fit and adjust an NTI-tss device as opposed to 17 minutes (range: 11-26 minutes) for making interocclusal records, taking impressions, and adjusting the surface of a stabilization appliance. Indeed, this computation appears to be debatable. In a previous study it was shown that the average time required for chair-side adjustment of a stabilization appliances (fabricated without and with face-bow) was less than $11 \mathrm{~min}$ utes (range: 4-27 minutes) [58]. To determine centric relation by fabricating an interocclusal record and to make alginate impressions of the upper and lower jaw one may calculate additional 15 minutes. Hence, for making a stabilization appliance the dentist needs to be at the chair for about 25 to 30 minutes, which corresponds to the time frame reported by Magnusson et al [9] for preparing an NTI-tss device. Yet, it should be noted that an inexperienced clinician may need considerably more time for either device.

The occlusal stabilization splint [59] remains the "gold standard" for the therapy of patients with (particularly localized) temporomandibular pain (i.e., myofascial pain of the masticatory muscles; TMJ arthralgia) and/or bruxism because it "is an easily used, potentially long-term, and clinically effective treatment intervention with reasonable nightly patient compliance and good outcomes," thereby exhibiting "few potential complications [2]."

\section{Conclusion}

There is evidence from RCTs that the NTI-tss bite stop may be successfully used for the management of TMDs and bruxism. However, to avoid potential side-effects, it must be ensured that the patient is willing to return regularly to the dentist's office for control sessions and, if needed, readjustments. If this prerequisite is fulfilled, the NTI-tss splint may be particularly justified in the following clinical situations:

- A patient with acute and intense temporomandibular pain (possibly accompanied by a restricted jaw opening), who requires (as an emergency therapy) the rapid incorporation of an oral appliance to increase the vertical dimension of the jaws.

- A reduction of the EMG activity of jaw closing muscles during jaw clenching or tooth grinding is desired.

\section{Competing interests}

The authors declare that they have no competing interests.

\section{Authors' contributions}

JCT designed the systematic review, HS carried out the systematic literature search. HS and JCT appraised the identified publications, and drafted the manuscript. Both authors read and approved the final manuscript.

\section{Acknowledgements}

We are grateful to Dr Babür Taner, DDS, Dr. Med. Dent., University of Basel, for the translation of the thesis by Y. Kavaklı (2006) from Turkish into German.

\section{References}

I. NTI-tss User's Guidebook [http://www.nti-tss.com/NTItssUser'sGuide.doc]

2. Clark GT, Minakuchi H: Oral appliances. In TMDs An EvidenceBased Approach to Diagnosis and Treatment Edited by: Laskin DM, Greene CS, Hylander WL. Chicago: Quintessence; 2006:377-390.

3. Was die Experten dazu sagen [http://www.e-motion.eu.com/ index.php?name $=$ avis specialistes de]

4. Brace that could cure migraine [http://www.migraine-den tistry.co.uk/testimonials.html]

5. AAAAAHMAZING! Device may help relieve migraines [http://www.nti-tss.ca/pages/pr/OttawaSun.html]

6. Taking a bite out of headache pain [http://www.usatoday.com/ news/health/2003-08-04-migraine-device x.htm]

7. Coker R: A Rosetta stone for restorative dentistry. ACEstethics 2006:15-16.

8. Helkimo M: Request for expert statement regarding the use of NTI-splint Stockholm: Socialstyrelesen. National Board of Health and Welfare. Dnr 53-5294I2003; 2003.

9. Magnusson T, Adiels AM, Nilsson HL, Helkimo M: Treatment effect on signs and symptoms of temporomandibular disorders - comparison between stabilisation splint and a new type of splint (NTI). A pilot study. Swed Dent J 2004, 28: I I-20.

10. Jokstad A, Mo A, Krogstad BS: Clinical comparison between two different splint designs for temporomandibular disorder therapy. Acta Odontol Scand 2005, 63:218-226.

II. Wetenschappelijk gefundeerde behandeling van temporomandibulaire dysfunctie. Bezint eer ge begint! [http:// beheer.ntvt.nl/UserFiles/PDF/NV 0106 014.pdf]

12. Wright EF, Jundt JS: The NTI appliance for TMD and headache therapy. Tex Dent J 2006, I 23: I I I8- I I 24.

13. Accidental swallowing of an incisal splint [http://
] www.tannlegetidende.no/pls/dntt/ pa dtdm.xpnd?.vp seks id $=\mid 13910$ \&b start $=1]$

14. Antes G: Evidence-based medicine. Internist 1998, 39:899-908.

15. Jadad AR, Moore RA, Carroll D, Jenkinson C, Reynolds DJM, Gavaghan $D J, M c Q u a y ~ H J$ : Assessing the quality of reports of randomized clinical trials: is blinding necessary? Control Clin Trials 1996, 17:1-12.

16. Shankland WE: Migraine and tension-type headache reduction through pericranial muscular suppression: a preliminary report. Cranio 2001, 19:269-278.

17. Shankland WE: Nociceptive trigeminal inhibition-tension suppression system: a method of preventing migraine and tension headaches. Compend Contin Educ Dent 2001, 22:1075-1080. [corrected and republished 2002;23: 105-108,II0,II2-II3]

18. Shankland WE: Nociceptive trigeminal inhibition-tension suppression system: A method of preventing migraine and tension headaches. Compend Contin Educ Dent 2002, 23:105-108.

19. TMD therapy using two occlusal splint designs [http:// iadr.confex.com/iadr/2004Hawaii/techprogram/abstract 40454.htm]

20. Mo A, Jokstad A, Krogstad BS, Dahl BL: A clinical comparison between two different splint designs for TMD therapy. Nor Tannlegeforen Tid 2004, I I 4:822-827.

21. Kavaklı Y: Polisomnografi ile teșhis edilen uyku bruksizmli hastaların tedavisinde iki farklı apareyin etkinliğinin değerlendirilmesi [Evaluation of effectiveness of two differ- 
ent appliances in treatment of patients with sleep bruxism diagnosed with polysomnography]. In PhD Thesis Hacettepe University, Health Sciences Institute; 2006.

22. Baad-Hansen L, Jadidi F, Castrillon E, Thomsen PB, Svensson P: Effect of a nociceptive trigeminal inhibitory splint on electromyographic activity in jaw closing muscles during sleep. J Oral Rehabil 2007, 34:105-III.

23. Electromyographic evaluation of the effect of two types of occlusal splints on the muscle activity in the decubitus position [http://iadr.confex.com/iadr/2002SanDiego/techprogram/ abstract 21586.htm]

24. Refleximetric evaluation of severe TMD treated with different therapies [http://iadr.confex.com/iadr/2004Hawaii/techpro gram/abstract 43898.htm]

25. Avaliação da extrusão dentária com o uso da mini placa NTItss no trattamento da cefaléia e do bruxismo [http://www.ntitss.com.br/artigos/NTI\%20SPBqO\%202006.pdf

26. Treatment and follow-up of referred otic symptomatology in 23 patients with diagnosed temporomandibular disorders [http://www.informaworld.com/smpp/35862199-71799553/con tent $\sim$ content $=\mathrm{a} 749290349 \sim \mathrm{db}=\mathrm{all} \sim$ order=page]

27. Fitins D: Överbelastade incisiver - en effekt av NTI-skenan. Ajour Odont 2002, 3:5.

28. Straus SE, Richardson WS, Glasziou P, Haynes RB: Evidence-Based Medicine. How to Practice and Teach EBM 3rd edition. Edinburgh: Churchill Livingstone; 2005.

29. Barton S: Which clinical studies provide the best evidence? The best RCT still trumps the best observational study. BMJ 2000, $321: 255-256$

30. Hackshaw A, Paul E, Davenport E: Evidence-Based Dentistry. An Introduction Oxford: Blackwell Munksgaard; 2006.

31. The Alpha-Tocopherol Beta Carotene Cancer Prevention Study Group: The effect of vitamin $E$ and beta carotene on the incidence of lung cancer and other cancers in male smokers. $\mathrm{N}$ Engl J Med 1994, 330:1029-1035.

32. Rossouw JE, Anderson GL, Prentice RL, LaCroix AZ, Kooperberg C, Stefanick ML, Jackson RD, Beresford SA, Howard BV, Johnson KC, et al: Risks and benefits of estrogen plus progestin in healthy postmenopausal women: principal results from the Women's Health Initiative randomized controlled trial. J $\mathrm{Am}$ Med Assoc 2002, 288:32I-333.

33. Bielakovic G, Nikolova D, Gluud LL, Simonetti RG, Gluud C: Mortality in randomized trials of antioxidant supplements for primary and secondary prevention: systematic review and meta-analysis. JAMA 2007, 297(8):842-857.

34. Headache Classification Subcommittee of the International Headache Society: The International Classification of Headache Disorders. Cephalalgia 2004, 24 Suppl I:9-160.

35. Glaros A, Urban D, Locke J: Headache and temporomandibular disorders: evidence for diagnostic and behavioural overlap. Cephalalgia 2007, 27:542-549.

36. Graff-Radford SB: Temporomandibular disorders and headache. Dent Clin North Am 2007, 5 I:I29-I44.

37. Van Eijden TMGV, Blanksma NG, Brugman P: Amplitude and timing of EMG activity in the human masseter muscle during selected motor tasks. J Dent Res 1993, 72:599-606.

38. Visser A, Naeije M, Hansson TL: The temporal/masseter co-contraction: an electromyographic and clinical evaluation of short-term stabilization splint therapy in myogenous CMD patients. J Oral Rehabil 1995, 22:387-389.

39. Becker I, Tarantola G, Zambrano J, Spitzer S, Oquendo D: Effect of a prefabricated anterior bite stop on electromyographic activity of masticatory muscles. J Prosthet Dent 1999, 82:22-26.

40. Stohler CS: Clinical decision-making in occlusion: a paradigm shift. In Science and Practice of Occlusion Edited by: McNeill C. Chicago: Quintessence; 1997:294-305.

4I. Kato T, Thie NM, Huynh N, Miyawaki S, Lavigne G]: Topical review: sleep bruxism and the role of peripheral sensory influences. J Orofac Pain 2003, 17:191-213.

42. Kreiner M, Betancor E, Clark GT: Occlusal stabilization appliances. Evidence of their efficacy. J Am Dent Assoc 200I, 132:770-777.

43. Al-Ani MZ, Davies SJ, Gray RJM, Sloan P, Glenny AM: Stabilization splint therapy for temporomandibular pain dysfunction syndrome (Cochrane review). In The Cochrane Library Issue I Chichester, UK: John Wiley \& Sons; 2004.
44. Forssell H, Kalso E: Application of principles of evidence-based medicine to occlusal treatment for temporomandibular disorders: are there lessons to be learned? J Orofac Pain 2004, 18:9-22.

45. Türp JC, Komine F, Hugger A: Efficacy of stabilization splints for the management of patients with masticatory muscle pain. A qualitative systematic review. Clin Oral Invest 2004, 8: I79-194.

46. Raphael KG, Marbach JJ: Widespread pain and the effectiveness of oral splints in myofascial face pain. J Am Dent Assoc 200I, 132:305-316.

47. Nilner M, Doepel M, Ekberg EC, Andersson J, Selovuo K, LeBell Y: The effectiveness of a prefabricated occlusal appliance in patients with myofascial pain. 25th Conference of the Society of Oral Physiology; May 24-27; Naantali, Finland 2007.

48. Al Quran FA, Kamal MS: Anterior midline point stop device (AMPS) in the treatment of myogenous TMDs: comparison with the stabilization splint and control group. Oral Surg Oral Med Oral Pathol Oral Radiol Endod 2006, 101:741-747.

49. Blanksma NG, van Eijden TM: Electromyographic heterogeneity in the human temporalis and masseter muscles during static biting, open/close excursions, and chewing. J Dent Res 1995, 74: I318-1327.

50. Blanksma NG, van Eijden TM, van Ruijven LJ, Weijs WA: Electromyographic heterogeneity in the human temporalis and masseter muscles during dynamic tasks guided by visual feedback. I Dent Res 1997, 76:542-55 I.

5I. Schindler HJ, Türp JC, Blaser R, Lenz J: Differential activity patterns in the masseter muscle under simulated clenching and grinding forces. J Oral Rehabil 2005, 32:552-563.

52. Schindler HJ, Rong Q, Spieß WEL: Der Einfluss von Aufbissschienen auf das Rekrutierungsmuster des Musculus temporalis. Dtsch Zahnärztl Z 2000, 55:575-58I.

53. Schindler HJ, Türp JC: Der Einfluss von experimentell erzeugtem Schmerz auf das Aktivierungsmuster des $\mathbf{M}$. masseter. Dtsch Zahnärztl Z 200I, 56:266-269.

54. Türp JC, Schindler HJ, Pritsch M, Rong Q: Antero-posterior activity changes in the superficial masseter muscle after exposure to experimental pain. Eur J Oral Sci 2002, I I 0:83-91.

55. Schindler HJ, Rues S, Türp JC, Lenz J: Heterogeneous activation of the medial pterygoid muscle during simulated clenching. Arch Oral Biol 2006, 51 : 498-504.

56. Schindler H-J, Svensson P: Myofascial temporomandibular disorder pain. Pathophysiology and management. In The Puzzle of Orofacial Pain Integrating Research Into Clinical Management Edited by: Türp JC, Sommer C, Hugger A. Basel: Karger; 2007:9I-123.

57. List T, Helkimo M: Adverse events of acupuncture and occlusal splint therapy in the treatment of craniomandibular disorders. Cranio 1992, 10:318-324. discussion 324-316

58. Shodadai SP, Türp JC, Gerds T, Strub JR: Is there a benefit of using an arbitrary face-bow for the fabrication of a stabilization appliance? Int J Prosthod 200I, 14:517-522.

59. Ramfjord SP, Ash MM: Reflections on the Michigan occlusal splint. J Oral Rehabil 1994, 21:49I-500.

60. Bender SD: The NTI appliance for TMD and headache therapy. Tex Dent J 2007, I 24:357-358. author reply 359-360

61. Blumenfeld A: The NTI appliance for TMD and headache therapy. Tex Dent J 2007, I 24:356. author reply 359-360

62. King M: The discussion about the NTI. Tex Dent J 2007, I 24:566.

63. FDA 5 I O(k) Premarket Notification \#KO 0876 (FDA's Summary) of the NTI Tension Suppression System [http:// www.nti-tss.com/migraineprevention.html]

64. A utilização das placas oclusais no controle das disfunções temporomandibulares (DTMs) [http://www.apcd.org.br/ciosp/
[ anais/Capitulos/Cap08 padrao.pdf

65. Bursitis hamular. Sintomatología ótica y craneofacial referida [http://encolombia.com/medicina/otorrino/otorrino3/303suplbursitis.htm]

66. Boyd JP: Domando as forças que ameaçam a odontología do día a día. Postgraduate Dentistry 2000.

67. Shankland WE: Temporomandibular disorders: Standard treatment options. Gen Dent 2004:349-355.

68. Hedge V: A review of the disorders of the temporomandibular joint. J Indian Prosthodont Soc 2005, 5:56-6I.

69. Yap AUJ: Bruxism: Something to chew on?! Dental Asia 2005.

70. Omarjee R: Le bruxisme du sommeil - mieux le comprendre pour mieux le prendre en charge. In Diplome d'état de docteur en 
chirurgie dentaire Université Bordeaux 2 - Victor Segalen, UFR d'odontologie; 2006.

71. Intraoral discluder and method for relieving migraine and tension headaches and temporomandibular disorders [http:l /www.freepatentsonline.com/20050288624.html]

72. Dentists can help with problem snoring and OSA [http:// www.tdgp.com.au/pdfs/Tropical Ear Feb 07.pdf]

73. The vanishing line between function and parafunction [http:l] /www.docere.com/Dentaltown/Article.aspx?aid=66I]

74. Blumenfeld A: Reduction of a refractory migraine through prevention of nocturnal trigeminal hyperactivity with an incisalonly contact device. In 48th Annual Scientific Meeting of the American Headache Society Los Angeles, CA; 2006.

75. Anti-tension device for teeth eases headache [http:// www.postgazette.com/healthscience/200107/7hgrind3.asp]

76. Davis RJ: Gadgets to take on pain. The Wall Street Journal . 16 December 2002

77. Blumenfeld A, Boyd JP: A migraine treatment patients can really sink their teeth into. Pract Neurol 2005, 4:45.

78. A pedra de Roseta na Dentística Restauradora [http:// www.nti-tss.com.br/artigos/NTI\%20\%20A\%20Pedra\%20de\%20Roseta.pdf

79. Uso do NTI-tss para o tratamento da DTM muscular em pacientes com aparartologia ortodôntica fixa [http:// www.nti-tss.com.br/artigos/painel\%20NTI-Tss\%202.jpg]

80. Instalação de dispositivo oclusal parcial anterior pré-fabricado [http://www.nti-tss.com.br/artigos/painel nti.jpg]

8I. Bezähmung der Muskelkräfte, welche die tägliche Zahnmedizin bedrohen [http://www.hkdent.de/fileadmin/DateiLinks/ Anwenderberichte/NTlemotion.pdf]

82. Fraczak B: Szyny NTI w leczeniu zespołów bólowych w obrêbie głowy - opis przypadku [Treatment of pain syndromes of the head with the use of NTI splint - case report]. Forum Stomatologiczne Tom II 2005, 4:230-233.

83. Blumenfeld A, Boyd JP: Intractable migraine headache reduction with a targeted approach to reduce trigeminal nerve activity using the NTI tension suppression system: A case study. In 48th Annual Scientific Meeting of the American Headache Society Los Angeles, CA; 2006.

84. Adverse event report: NTI clenching suppression system. NTI splint nociceptive trigeminal inhibition reflex device [http://www.accessdata.fda.gov/scripts/cdrh/cfdocs/cfMAUDE/ Detail.CFM?MDRFO| ID $=47|0| 8]$

85. Adverse event report: Keller Labs NTI-tss dental device to stop nighttime clenching and grinding [http://www.access data.fda.gov/scripts/cdrh/cfdocs/cfMAUD

Deil.CFM?MDRFOI ID $=551955]$

86. Adverse event report: NTI-tss NTI-tss tension supression system for bruxism [http://www.accessdata.fda.gov/scripts/cdrh/ cfdocs/cfMAUDE/Detail.CFM?MDRFOI ID $=557167]$

87. Adverse event report: NTI-tss Inc. NTI-tss dental implant [http://www.accessdata.fda.gov/scripts/cdrh/cfdocs/cfMAUDE/ Detail.CFM?MDRFOI ID $=753670]$

88. Adverse event report: Keller Laboratories NTI - tension suppression system TM] [http://www.accessdata.fda.gov/scripts/ cdrh/cfdocs/cfMAUDE/Detail.CFM?MDRFOI ID=765535]

89. Boyd JP, Shankland WE, Brown C, Schames J: Taming the muscular forces that threaten everyday dentistry. Postgrad Dent 2000

90. Leder S: Funktionsstörungen wirksam, schnell und wirtschaftlich behandeln. GZM Prax Wissensch 2006, I I(3):44-46.

91. Christensen G]: Occlusion confusion. Dentaltown 2006:8-14.

92. N.N: Occlusal splint. Clin Res Ass Newslet 2000, 24:

93. N.N: Preventing clenching and bruxism problems using the Tension Suppression System. Dental Products Report 200I.

94. Lennros H: NTI- incisalskenan: utredning, behandling och resultat. In Lecture at Odontologisk Riksstämma; Stockholm The Annual Dental Congress for the Swedish Dental Society; 2002.

95. Helkimo M: The NTI splint does not qualify the requirements as lege artis. Tandläkartidningen 2003.

96. N.N: NTI-TSS. Reality 2004, I 8:.

97. Bury L: Faut-il craquer pour le NTI-tss? Indépendentaire 2005:152-155.

98. Zahn auf Zahn. Knirschend und pressend zur Migräne [http:/ /www.karrdental.ch/]
99. Pham G, Serhan I: Restaurations prothétiques esthétiques chez le patient bruxomane: gestion du risque. Stratégie prothétique 2006, 6(5): $1-8$.

100. Bruxisme: mieux comprendre pour mieux traiter [http://emotion.eu.com/medias/documents/ FR $2006 \quad 10$ FilDentaire Focus Clinic.pdf]

I0I. Mutel Y: Wirksames Hilfsmittel zur Muskelentspannung in der Kieferorthopädie. Kieferorthop Nachr . without year

102. Stós B: Occlusal splints which are commonly used in prosthodontic treatment of temporo-mandibular dysfunction (manuscript). . without year

103. Muscular parafunction of the masticatory system: headache, face, jaw, and sinus pain (temporomandibular disorders) [http:oks.google.cooks? id=L2CSdeiMZi4C\&pg=PA207\&lpg=PA20mu scularafunction+of+the+masticatory+system+head ache+face+jaw+and+sinus + pain+temporomandibu lar+disrs\%22\&source=web\&ots=Ldo6v6XGMv\&sig=Gtup6UzEU65jin gtRcMc]

104. Hornbrook D: A conversation with Dr James Boyd. Australasian Dentist 2004, 7:30-34.

105. Dental Practice Report. Dr. David Hornbrook interviews Dr. James Boyd [http://www.headacheprevention.com/ index.php?option=com content\&task=view\&id= 19\&ltemid=38]

106. Duffner K: Weniger Spannung. Biofeedback gegen Zähneknirschen. Dental World 2006:4-5.

107. Stanley M: Sistema de supressão de tensão através da inhibição do aparelho nociceptivo do trigémino. Dentistry Clínica 2006:20-21.

108. Lazaroo B: Le NTI-tss vu par le Dr. Lazaroo. L'Information Dentaire 2006, 88:

109. Pham G: Le système NTI-tss vu par un omnipracticien. L'Information Dentaire 2005, 87:20.

I10. Interview with Dr. Jim Boyd [http://www.kellerlab.com/docu ments/KellerFall2005ENews 00I.pdf]

III. Dworkin SF, LeResche L: Research diagnostic criteria for temporomandibular disorders: review, criteria, examinations and specifications, critique. I Craniomandib Disord 1992, 6(4):30I-355

\section{Pre-publication history}

The pre-publication history for this paper can be accessed here:

\section{http://www.biomedcentral.com/1472-6831/8/22/prepub}

Publish with Bio Med Central and every scientist can read your work free of charge

"BioMed Central will be the most significant development for disseminating the results of biomedical research in our lifetime."

Sir Paul Nurse, Cancer Research UK

Your research papers will be:

- available free of charge to the entire biomedical community

- peer reviewed and published immediately upon acceptance

- cited in PubMed and archived on PubMed Central

- yours - you keep the copyright

Submit your manuscript here:

http://www.biomedcentral.com/info/publishing_adv.asp
BioMedcentral 